\title{
Kontribusi Parenting School Terhadap Hasil Belajar PPKN Peserta Didik Kelas V SD Negeri no. 25 Panaikang KecamatanBissappu Kabupaten Bantaeng
}

\author{
Kartini $^{1}$, Andi Kasmawati ${ }^{2}$, Sangkala Ibsik ${ }^{3}$ \\ ${ }^{123}$ Pendidikan Ilmu Pengetahuan Sosial, Universitas Negeri Makassar \\ 1Email: kartini.darongdewi23@gmail.com
}

\begin{abstract}
Abstrak: Penelitian ini adalah penelitian kuantitatif yang bertujuan untuk membuktikan dan mendeskripsikan kontribusi parenting school terhadap hasil belajar peserta didik kelas V pada mata pelajaran PPKn di SD Negeri No. 25 Panaikang Kecamatan Bisappu Kabupaten Bantaeng. Variabel bebas dalam penelitian ini adalah parenting school dan variabel terikat penelitian adalah hasil belajar PPKn siswa. Populasi dalam penelitian ini adalah siswa kelas V SD Negeri No. 25 Panaikang Kecamatan Bisappu Kabupaten Bantaeng sebanyak 50 siswa yang sekaligus menjadi sampel penelitian dengan pertimbangan jumlah populasi yang kurang dari 100 orang. Data penelitian ini diperoleh melalui kuesioner yang diisi oleh orang tua siswa dan dokumentasi dengan melihat nilai PPKn siswa. Data yang diperoleh kemudian dianalisis dengan menggunakan uji statistik. Hasil penelitian ini menyatakan bahwa Terdapat kontribusi yang diberikan oleh parenting school terhadap hasil belajar PPKn Peserta Didik Kelas V SD Negeri No. 25 Panaikang Kecamatan Bisappu Kabupaten Bantaeng. Hal tersebut berdasarkan hasil uji korelasi product moment pada penelitian ini yaitu $R_{\text {hitung }} 0,467$ lebih besar daripada nilai $R_{\text {tabel }} 0,279$ Berdasarkan hasil perhitungan koefisien korelasi diperoleh nilai 0,467 yang masuk dalam kategori hubungan sedang, dan berdasarkan perhitungan garis regresi didapatkan hasil $\mathrm{Y}=52,5988+0,640$ yang dapat diartikan bahwa terdapat pengaruh yang positif karena nilai konstanta a adalah + 0,640 . Hasil tersebut diartikan bahwa nilai parenting school bertambah 1 poin maka akan menambah nilai hasil belajar siswa sebanyak 0,640 serta nilai koefisien determinasi $21,8 \%$ yang berarti parenting school memberikan kontribusi sebesar 21,8\% terhadap hasil belajar siswa PPKn siswa kelas V SD Negeri No. 25 Kecamatan Bisappu Kabupaten Bantaeng.
\end{abstract}

Kata Kunci; Kontribusi, Parenting School, Hasil Belajar

\begin{abstract}
This research is qualitative reasearch which aims to prove and describe the contribution of parenting school to the PPKn learning outcomes of student in grade 5 SD Negeri No. 25 Kecamatan Bisappu Kabupaten Bantaeng. Theindependent variable in this study is the parenting school and the dependent variable is the studnt learning outcomes of PPKn. The population in this research wew 50 students in 5 grade SD Negeri No. 25 Kecamatan Bisappu Kabupaten Bantaeng who were at the same time be a reasearch sample with a consideration that the population was less than 100 people. The research data were obtained through a questionnaire fille out by the parents of students and documentation by looking at the student's PPKn learning outcome. The data obtained were then analyzed using statistical tests. The results of this research indicate that there is a contribution made by the parenting school to the learning outcimes of PPKn students of grade V SD Negeri No. 25 panaikang, Kecamatan Bisappu Kabupaten Bantaeng. This is based on the results of the product moment correlation test in this study, namely $\mathrm{R}$ count $0.467>\mathrm{R}$ table value is 0.279 The process of parenting school
\end{abstract}


contributions to student learning outcomes is in the medium category . Based on the results of the calculation of the correlation coefficient, the value is 0.467 which is included in the medium relationship category. In addition, based on the calculation of the regression line, the result is $\mathrm{Y}=52.5988+0.640$, which means that there is a positive influence because the constant a value is +0.640 . These results can also be interpreted that if the parenting school score increases by 1 point it will add to the value of student learning outcomes by 0.640 and value of determinant coefficient is $21,8 \%$ that means parenting school contribution is $21,8 \%$ to the PPKn learning outcome of student grade V SD Negeri No. 25 Panaikang Kecamatan Bisappu Kabupaten Bantaeng.

Key words: contribution, parenting school, learning outcome

Ini adalah artikel dengan akses terbuka dibawah licenci CC BY-NC-4.0

(https://creativecommons.org/licenses/by-nc/4.0/).

\section{PENDAHULUAN}

Peningkatan mutu pendidikan merupakan sasaran pembangunan di bidang pendidikan nasional dan merupakan bagian integral dari upaya peningkatan kualitas manusia Indonesia secara menyeluruh. Menteri Pendidikan Nasional telah mencanangkan "Gerakan Peningkatan Mutu" pada tanggal 2 Mei 2002 dan lebih terfokus lagi setelah diamanatkan dalam Undang- Undang 20 tahun 2003 tentang Sistem Pendidikan Nasional. Sistem Pendidikan Nasional menjelaskan bahwa pendidikan nasional berfungsi mengembangkan kemampuan dan membentuk watak serta peradaban bangsa yang bermartabat dalam rangka mencerdaskan kehidupan bangsa, bertujuan untuk bertakwa kepada Tuhan Yang Maha Esa, berakhlak mulia, sehat, berilmu, cakap, berkembangnya potensi peserta didikagar menjadi manusia yang beriman, kreatif, mandiri, dan menjadi warga negara yang yang demokratis serta bertanggung jawab.

Salah satu hal yang erat kaitannya dengan Sistem Pendidikan Nasional adalah sekolah. Sekolah merupakan suatu organisasi yang memerlukan pengelolaan terpadu oleh guru sebagai pelaksana kegiatan pembeljaran di kelas maupun oleh kepala sekolah sebagai pengendali kegiatan di sekolah. Selain sekolah, wadah untuk membentuk kemampuandan watak peserta didik adalah keluarga dan masyarakat. Keluarga merupakan tempat pertama pendidikan itu mulai muncul ketika anak masih berada di dalam kandungan, bagaimana seorang ibu melakukan komunikasidengan bayinya yang ada di dalam perut hingga anak itu lahir dididik dan dibesarkan dengan penuh suka cita. Keluarga dan masyarakat memegang peranan yang paling besar dalam membentuk kepribadian anak sebelum anak mengenal dunia sekolah. Komunikasi yang terjadi dengan keluarga dan masyarakat merupakan rangsangan yang utama, karena waktu bersama anak lebihbanyak dihabiskan dalam lingkungan keluarga dan masyarakat jika dibandingkan dengan waktu anak berada dalam sebuah lembaga pendidikan.

Perkembangan anak berlangsung secara berkesinambungan, yang berarti bahwa tingkat perkembangan yang dicapai pada suatu tahap diharapkan meningkat baik secara kuantitatif maupun secara kualitatif pada tahapselanjutnya. Agar anak mencapai tingkat perkembangan yang optimal, dibutuhkan keterlibatan orang tua dan orang dewasa untuk memberikan rangsangan yang bersifat menyeluruh dan terpadu yang meliputi pendidikan, pengasuhan, kesehatan, gizi, dan perlindungan yang diberikan secara konsisten melalui pembiasan (Depdiknas, 2010: 3).

Adanya pembiasan-pembiasan yang baik yang diberikan oleh orang tua kepada peserta didik sehingga dengan sendirinya pembiasan itu berubah menjadi suatu kedisiplinan. Displin merupakan suatu kesadaran yang tinggi terhadap diri yangmuncul dari batin yang terdalam untuk mengikuti dan menaati peraturan-peraturan, nilai-nilai, dan hukum yang berlaku dalam suatu lingkungan tertentu Disiplin adalah salah satu yang menjadi sasaran dalam pendidikan. Disiplin berperan memengaruhi, mendorong, mengendalikan, mengubah, membina, dan membentuk perilakuperilaku tertentu sesuai dengan nilai-nilai yang 
ditanamkan, diajarkan, dan diteladankan dalam mendidik. Oleh karena itu, perubahan perilaku seseorang termasuk prestasinya merupakan hasil dari suatu proses pendidikan dan pembelajaran yang terencana, informal, atau otodidak.

Keterlibatan orang tua menjadi hal yang penting dalam pengasuhan dan pembimbingan peserta didik karena pendidikan keluarga merupakan pendidikan yang pertama dan utama yang memiliki pengaruh besar terhadap perilaku individu. Orang tua sebagai pendidik pertama dan utama tidak tersiapkan, belum bersinergi antara pendidikan di sekolah, keluarga, dan masyarakat, merupakan berbagai ancaman terhadap perkembangan generasi muda. Sehingga dapat dikatakan bahwa peran serta orang tua dalam mendidik dan membimbing peserta didik salah satu karakter yang ingin dikembangkan dan berkesinambungan adalah terciptanya kedisiplinan kepada diri anak yang dengan kedisiplinan tersebut akanmengantarkan anak atau peserta didik mencapai prestasinya sebagaimana pernyataan Djamarah (2006:23) yang mengatakan bahwa untuk menghasilkan prestasi belajar yang bagus tentu dituntut disiplin siswa dalam belajar ayau dalam proses itu sendiri.

Pemerintah Kabupaten Bantaeng pada tahun 2016 bekerja sama dengan Kementrian Pendidikan dan Kebudayaan Republik Indonesia telah melaksanakan "Program Pendidikan Keluarga" dan telah dilaksanakan oleh beberapa sekolah yang ada di Kabupaten Bantaeng, salah satunya adalah SD Negeri No 25 Panaikang. Program "Kegiatan Parening School" menjadi program unggulan dalam program pendidikan keluarga tersebut. Parenting school adalah kegiatan yang melibatkan orang tua dalam kegiatan sekolah yang bertujuan untuk meningkatkan prestasi belajar peserta didik.

Mata Pelajaran PPKn bertujuan agar peserta didik memiliki kemampuan sebagai berikut: (1) berpikir secara kritis, rasional, dan kreatif dalam menanggapi isu kewarganegaraan; (2) berpartisipasi secara aktif dan bertanggung jawab, dan bertindak secara cerdas dalam kegiatan bermasyarakat, berbangsa, dan bernegara, serta anti-korupsi; (3) berkembang secara positif dan demokratis untuk membentuk diri berdasarkan karakter- karakter masyarakat Indonesia agar dapat hidup bersama dengan bangsa-bangsa lainnya; (4) berinteraksi dengan bangsa-bangsa lain dalam peraturan dunia secara langsung atau tidak langsung dengan memanfaatkan teknologi informasi dan komunikasi. Berdasarkan tujuan tersebut, maka materi dalam pembelajaran PKKn perlu diperjelas.

Hasil observasi awal peneliti pada pelaksanaan pembelajaran PPKn di SD Negeri No 25 Panaikang peserta didik kelas $\mathrm{V}$, pembelajaran PPKn masih belum terlaksana dengan optimal. Hal itu disebabkan karena guru kurang menggunakan variasi pembelajaran yang inovatif, peserta didik kurang aktif dalam proses pembelajaran, minat belajar pesrta didik rendah sehingga hasil belajar peserta didik rendah. Hal ini diperkuat dengan bukti dari pencapaian nilai rata-rata hasil ulangan harian PKn peserta didik kelas $\mathrm{V}$ masih banyak yang mendapatkan nilai di bawah Kriteria Ketuntasan Minimal (KKM) yang ditetapkan sekolah yaitu 70. Data hasil belajar Pesrta didik menunjukkan $(66,67 \%) 19$ pesrta didik yang belum tuntas dari 30 pesrta didik.

Tabel 1 Rekapitulasi Hasil Semester ganjil Mata Pelajaran PPKn Kelas V ${ }^{a}$ SD Negeri No 25 Panaikang.

\begin{tabular}{rrrrrrl}
\hline Nilai & \multicolumn{2}{c}{$\begin{array}{l}\text { JumlahPesrta } \\
\text { didik }\end{array}$} & Persentase(\%) & & Keterangan & \\
\hline & $<\mathbf{7 0}$ & 19 & 66,67 & $\begin{array}{l}\text { Belum } \\
\text { Tuntas }\end{array}$ & \\
& & & & & & \\
& $>\mathbf{7 0}$ & 11 & 33,33 & Tuntas & \\
\hline Jumlah & & $\mathbf{3 0}$ & $\mathbf{1 0 0 , 0 0}$ & & - \\
\hline
\end{tabular}

Aktivitas selama pembelajaran diketahui: (1) peserta didik kurang memperhatikan ketika guru memberikan pelajaran di kelas; (2) keaktifan berinteraksi atau berdiskusi untuk memecahkan masalah antar peserta didik maupun dengan guru masih kurang; (3) kurang aktifnya peserta didik untuk membaca dan mengerjakan soal- 
soal latihan; (4) keaktifan peserta didik dalam mengkomunikasikan hasil kerja kelompok masih kurang.

Guru PPKn di SD Negeri No 25 Panaikang menggunakan metode ceramah sebagai metode yang dominan, dengan mengharapkan peserta didik duduk mendengarkan guru menjelaskan dengan tertib kemudian mencatat hasil yang disampaikan oleh guru. Cara penyampaian materi pembelajaran yang kurang aktif membuat suasana kelas tidak hidup hal ini kurangnya interaksi antar pesrta didik itu sendiri dan menyebabkan proses belajar mengajar menjadimonoton atau kaku.

Parenting school sangat efektif dalam pembinaan pendidikan dalam lingkungan eluarga peserta didik. Oleh karena itu, terdapat perbedaan dalam penelitian ini sehingga menjadikan aspek kebaharuan dalam penelitian ini yang mengukur hubungan parenting school terhadap hasil belajar peserta didik terutama dalam pembelajaran PPKn dijenjang Sekolah Dasar. Hasil belajar PPKn peserta didik dinilai kurang, sehingga dengan keterlibatan orang tua dalam pembinaan lebih lanjut dapat dijadikan solusinya.

Berdasarkan uraian di atas, dalam rangka ikut berpartisipasi meningkatkan mutu pendidikan di SD melalui program pendidikan keluarga khususnya mutu pendidikan di Kabupaten Bantaeng, maka penulis tertarik untuk mengadakan penelitian mengenai "Kontribusi Parenting School terhadap Hasil Belajar Peserta Didik pada Mata Pelajaran PPKn SD Negeri No. 25 Panaikang Kecamatan Bissappu Kabupaten Bantaeng”. Tujuan dari penelitian ini adalah membuktikan kontribusi parenting school yang diterapkanoleh orang tua siswa terhadap peserta didik kelas V SD Negeri No. 25 Panaikang Kecamatan Bisappu Kabupaten Bantaeng dan mendeskripsikan kontribusi parenting school terhadap hasil belajar peserta didik pada Mata Pelajaran PPKn SD Negeri No 25 Panaikang Kec. Bisappu Kabupaten Bantaeng.

\section{METODE}

Penelitian ini adalah penelitian kuantitatif dengan metode survei dan teknik korelasional. opulasi penelitian ini adalah siswa kelas V SD Negeri No. 25 Panaikang Kabupaten Bantaeng. Sampel penelitian ini adalah seluruh peserta didik kelas V SD Negeri No. 25
Panaikang Kabupaten Bantaeng. Teknik pengumpulan data berupa kuesioner dan dokumentasi. Instrumen penelitian berupa angket dan dokumentasi. Teknik analisis data yang dilakukan adalah menggunkana analisis deskriptif dan uji statistik korelasional.

\section{HASIL DAN PEMBAHASAN}

\section{A. Hasil Penelitian}

\section{Deskripsi Data Penelitian}

Data hasil penelitian terdiri dari variabel bebas yaitu; variabel Parenting School dan variabel terikat yaitu hasil belajar peserta didik kelas V pada mata pelajaran PPKn peserta didik SDN No.25 Panaikang Kecamatan Bissappu Kabupaten Bantaeng.

Pada bagian ini akan digambarkan atau dideskripsikan dari data masing-masing variabel yang telah diolah dilihat dari nilai ratarata (mean), median, modus, dan standar deviasi. Selain itu juga disajikan tabel distribusi frekuensi dan diagram batang dari distribusi frekuensi masing-masing variabel.

\section{a. Variabel Parenting School}

Data variabel Parenting School diperoleh melalui angket yang terdiri dari 33 item dengan jumlah responden 50 peserta didik. Ada 4 alternatif jawaban skor tertinggi 4 dan skor terendah 1. Data indikator Parenting School diperoleh melalui angket yang terdiri dari 30 item dengan jumlah responden 50 Peserta didik. Berikut ini disajikan tabel distribusi frekuensi data variabel parenting school.

Tabel 2. Distribusi Frekuensi Data Parenting School

\begin{tabular}{ccc}
\hline \multirow{2}{*}{ Rentang Nilai } & \multicolumn{2}{c}{ Frekuensi } \\
\cline { 2 - 3 } & $\begin{array}{c}\text { Frekuensi } \\
\text { Mutlak }\end{array}$ & $\begin{array}{c}\text { Frekuensi } \\
\text { Relatif }\end{array}$ \\
\hline $92-94$ & 1 & 2 \\
$95-97$ & 2 & 4 \\
$98-100$ & 6 & 12 \\
$101-103$ & 8 & 16 \\
$104-106$ & 9 & 18 \\
$107-109$ & 5 & 10 \\
$110-112$ & 9 & 18 \\
$113-116$ & 10 & 20 \\
\hline Jumlah & $\mathbf{5 0}$ & $\mathbf{1 0 0 \%}$ \\
\hline
\end{tabular}

Berdasarkan tabel 4.1 diperoleh data sebanyak 1 responden mendapat nilai parenting school di rentang 92-94 dengan 
presentase 2 persen, sebanyak 2 responden mendapat nilai parenting school di rentang 95-97 dengan presentase 4 persen, sebanyak 6 responden mendapat nilai parenting school di rentang 98-100 dengan presentase 12 persen, sebanyak 8 responden mendapat nilai parenting school di rentang 101-103 dengan presentase 16 persen, sebanyak 9 responden mendapat nilai parenting school di rentang 104-106 dengan presentase 18 persen, sebanyak 5 responden mendapat nilai parenting school di rentang 107-109 dengan presentase 10 persen, sebanyak 9 responden mendapat nilai parenting school di rentang 110-112 dengan presentase 18 persen, dan sebanyak 10 responden mendapat nilai parenting school di rentang 113-116 dengan presentase 20 persen. Selain itu, berdasarkan data indikator Parenting School, diperoleh skor tertinggi sebesar 116,00 dan skor terendah sebesar 93,00. Hasil analisis harga Mean (M) sebesar 106,48; Median (Me)

Tabel 3. Kategorisasi Angket

Parenting School

\begin{tabular}{cccc}
\hline \multirow{2}{*}{ Skor } & \multicolumn{2}{c}{ Frekuensi } & \\
\cline { 2 - 3 } & $\begin{array}{c}\text { Frekuensi } \\
\text { Mutlak }\end{array}$ & $\begin{array}{c}\text { Frekuensi } \\
\text { Relatif }\end{array}$ & Kategori \\
\hline $\begin{array}{c}\mathrm{X} \geq \\
136\end{array}$ & 0 & 0 & $\begin{array}{c}\text { Sangat } \\
\text { Tinggi }\end{array}$ \\
\hline $\begin{array}{c}112 \leq \\
\mathrm{X}< \\
136\end{array}$ & 10 & 20 & Tinggi \\
\hline $\begin{array}{c}88 \leq \mathrm{X} \\
<112\end{array}$ & 40 & 80 & Sedang \\
\hline $\begin{array}{c}64 \leq \mathrm{X} \\
<88\end{array}$ & 0 & 0 & Rendah \\
\hline $\mathrm{X}<64$ & 0 & 0 & $\begin{array}{c}\text { Sangat } \\
\text { Rendah }\end{array}$ \\
\hline Jumlah & $\mathbf{5 0}$ & $\mathbf{1 0 0 \%}$ &
\end{tabular}

Berdasarkan tabel 4.2 maka diperoleh data sebanyak 10 responden dengan presentase $20 \%$ masuk dalam kategori tinggi dalam parenting school. 40 responden dengan presentase $80 \%$ masuk dalam kategori sedang dalam parenting school. Sedangkan, tidak terdapat responden yang masuk dalam kategori sangat rendah, rendah, dan sangat tinggi. sebesar 106,00; Modus (Mo) sebesar 116.

Selanjutnya berdasarkan distribusi frekuensi data angket parenting school, dilakukan pengkategorian dengan hasil sebagaiberikut: BelajarPPKn

Tabel 4. Distribusi Frekuensi Hasil

\begin{tabular}{ccc}
\hline \multirow{2}{*}{$\begin{array}{c}\text { Rentang } \\
\text { Nilai }\end{array}$} & \multicolumn{2}{c}{ Frekuensi } \\
\cline { 2 - 3 } & $\begin{array}{c}\text { Frekuensi } \\
\text { Mutlak }\end{array}$ & $\begin{array}{c}\text { Frekuensi } \\
\text { Relatif }\end{array}$ \\
\hline $74-76$ & 1 & 2 \\
$77-79$ & 7 & 14 \\
$80-82$ & 7 & 14 \\
$83-85$ & 17 & 34 \\
$86-88$ & 10 & 20 \\
$89-91$ & 6 & 12 \\
$92-94$ & 2 & 4 \\
$95-97$ & 0 & 0 \\
\hline Jumlah & $\mathbf{5 0}$ & $\mathbf{1 0 0 \%}$ \\
\hline
\end{tabular}

Berdasarkan data yang diperoleh maka dapat disimpulkan bahwa tingkat parenting school orang tua peserta didik kelas V SD Negeri No. 25 Panaikang Kecamatan Bissappu kabupaten Bantaeng masuk dalam kategori sedang. Kesimpulan ini didasarkan pada kategori skor angket sebanyak $80 \%$ masuk dalam kategori sedang. Selain itu, nilai median 106,48 jika dikategorikan juga masuk dalam kategori sedang.

\begin{tabular}{|c|c|c|c|}
\hline \multirow[b]{2}{*}{ Nilai } & \multicolumn{2}{|c|}{ Frekuensi } & \multirow[b]{2}{*}{$\begin{array}{c}\text { Kategor } \\
\mathbf{i}\end{array}$} \\
\hline & $\begin{array}{l}\text { Frekuens } \\
\text { i Mutlak }\end{array}$ & $\begin{array}{c}\text { Frekuens } \\
\text { i Relatif }\end{array}$ & \\
\hline $80-100$ & 42 siswa & 84 & $\begin{array}{c}\text { Baik } \\
\text { Sekali }\end{array}$ \\
\hline $\begin{array}{l}66-79 \\
56-65\end{array}$ & $\begin{array}{c}8 \text { siswa } \\
0\end{array}$ & $\begin{array}{c}16 \\
0\end{array}$ & $\begin{array}{l}\text { Baik } \\
\text { Cukup }\end{array}$ \\
\hline
\end{tabular}

b. Variabel Hasil Belajar PPKn Peserta didik

Variabel hasil belajar Peserta didik dalam penelitian ini yaitu data variabel hasil belajar diperoleh dari nilai raport siswa SDN No.25 Panaikang Kecamatan Bissappu Kabupaten Bantaeng. Berikut ini disajikan tabel distribusi frekuensi hasil belajar PPKn 
peserta didik di SDN No. 25 Panaikang Kecamatan Bissappu Kabupaten Bantaeng.

Berdasarkan tabel 4.3 diperoleh data sebanyak 1 responden mendapat nilai hasil belajar di rentang 74-76 dengan presentase 2 persen, sebanyak 7 responden mendapat nilai hasil belajar di rentang 77-79 dengan presentase 14 persen, sebanyak 7 responden mendapat nilai hasil belajar di rentang 80-82 dengan presentase 14 persen, sebanyak 17 responden mendapat nilai hasil belajar di rentang 83-85 dengan presentase 34 persen, sebanyak 10 responden mendapat nilai hasil belajar di rentang 86-88 dengan presentase 20 persen, sebanyak 6 responden mendapat nilai hasil belajar di rentang 89-91 dengan presentase 12 persen, sebanyak 2 responden mendapat nilai hasil belajar di rentang 92-94 dengan presentase 4 persen, dan tidak ada yang mendapatkan nilai pada rentang 95-97. Selain itu, berdasarkan data nilai hasil belajar PPKn siswa, diperoleh skor tertinggi sebesar 93,00 dan skor terendah sebesar 76,00. Hasil analisis harga Mean (M) sebesar 84,16; Median (Me) sebesar 85,00; Modus (Mo) sebesar 85,00.

Selanjutnya distribusi frekuensi data hasil belajar PPKn siswa kelas V SD Negeri No. 25 Panaikang kecamatan Bissappu kabupaten Bantaeng dikategorisasikan. Hasil kategorisasi hasil belajar siswa dapat dilihat pada tabel berikut:

Tabel 4.4 Kategorisasi Hasil Belajar PPKn Peserta Didik Kelas V SD Negeri No. 25 Kecamatan Bissappu Kabupaten Bantaeng

\begin{tabular}{|c|c|c|c|}
$40-55$ & 0 & 0 & Kurang \\
$30-39$ & 0 & 0 & Gagal \\
\hline $\begin{array}{c}\text { Jumla } \\
\text { h }\end{array}$ & $\mathbf{5 0}$ siswa & $\mathbf{1 0 0 \%}$ & \\
\hline
\end{tabular}

Berdasarkan tabel 4.4 diperoleh data berdistribusi normal. Sedangkan untuk nilai hasil belajar PPKn siswa diperoleh nilai hasil uji normalitas sebesar 0,948657 dan nilai tabel Shapiro Wilk yang diperoleh untuk signifikansi $5 \%$ adalah 0,947 . Jikadibandingkan maka dihasilkan $0,948657>$ bahwa sebanyak 8 siswa dengan presentase $16 \%$ memiliki hasil belajar yang masuk dalam kategori baik. 42 siswa dengan presentase $84 \%$ masuk dalam kategori baik sekali. Sementara itu, tidak terdapat siswa yang masuk dalamkategori cukup, kurang, ataupun gagal. Berdasarkan hasil kategorisasi maka dapat disimpulkan jika hasil belajar siswa masuk dalam kategori baik sekali. Hal tersebut juga diperkuat dengan nilai mean 84,16 yang jika dikategorikan juga masuk dalam kategori baik sekali.

\section{Uji Prasyarat}

Sebelum pengujian hipotesis dilakukan maka terlebih dahulu dilakukan uji prasyarat. Uji prasyarat dilakukan untuk mengetahui kondisi data yang akan diuji. Uji prasyarat analisis bertujuan untuk meninjau kembali data yang dimiliki dan akan diuji hipotesis telah memenuhi syarat pengujian yang akan dilakukan atau tidak. Penelitian ini menggunakan uji normalitas dan uji linearitas.

\section{a. Uji Normalitas}

Uji normalitas dilakukan untuk mengetahui normal atau tidaknya data yang dimiliki. Uji normalitas yang dilakukan dalam penelitian ini adalah uji normalitas Shapirol Wilk. Berikut ini tabel hasil uji normalitas.

Tabel 4.5 Uji Normalitas Data

\begin{tabular}{|c|c|c|c|c|}
\hline No & Data & $\begin{array}{c}\text { Hasil } \\
\text { Uji } \\
\text { Shapiro } \\
\text { Wilk }\end{array}$ & $\begin{array}{c}\text { Nilai } \\
\text { Tabel } \\
\text { Shapir } \\
\text { o } \\
\text { Wilk }\end{array}$ & $\begin{array}{c}\text { Kesimp } \\
\text { ulan }\end{array}$ \\
\hline 1 & $\begin{array}{c}\text { Parenti } \\
\text { ng } \\
\text { School } \\
\text { Nilai } \\
2\end{array}$ & 0,95317 & 0,947 & Normal \\
& $\begin{array}{c}\text { Hasil } \\
\text { Belajar } \\
\text { PPKn }\end{array}$ & $\begin{array}{c}0,94865 \\
7\end{array}$ & 0,947 & Normal \\
\hline
\end{tabular}

Berdasarkan tabel 4.5 diperoleh hasil uji normalitas untuk data parenting school 0,95317 dan nilai tabel Shapiro Wilk yang diperoleh untuk signifikansi 5\% adalah 0,947. Jika dibandingkan maka dihasilkan 0,95317 > 0,947 yang berarti data parenting school 0,947 yang berarti data nilai hasil belajar PPKn siswa berdistribusi normal. Perhitungan uji normalitas selengkapnya dilampirkan pada lampiran $\mathrm{C} 1$ dan $\mathrm{C} 2$.

\section{b. Uji Liniearitas}

Uji liniearitas bertujuan untuk mengetahui apakah dua variabel memiliki hubungan yang liniear secara signifikan atau tidak. Adapun hasil uji liniearitas pada penelitian ini yaitu $F_{\text {hitung }} 0,39499935$ yang dibandingkan dengan 
nilai $F_{\text {tabel }} 4,04$ maka $0,39499935<4,04$ sehingga dapat disimpulkan bahwa data angket kuesioner dan data hasil belajar siswa linear. Hasil perhitungan lengkap uji liniearitas lengkap dilampirkan pada lampiran C3.

\section{Uji Hipotesis}

Uji hipotesis dilakukan untuk mengetahui kontribusi parenting school terhadap hasil belajar PPKn siswa SD No. 25 Panaikang Kecamatan Bissappu Kabupaten Bantaeng. Uji hipotesis yang dilakukan adalah uji korelasi Product Moment Karl Pearson, uji parsial, menghitung garis regresi, dan menghitung regresi linier sederhana.

a. Uji Korelasi Product Moment

Adapun variabelnya adalah sebagai berikut:X : kontribusi parenting school

Y : hasil belajar PPKn siswa kelas V SD

No. 25 Panaikang Kecamatan Bissappu

KabupatenBantaeng.

Hipotesis:

$H_{1}=$ ada pengaruh antara variabel $\mathrm{X}$ dan variabel $\mathrm{Y}$

$H_{0}=$ tidak ada pengaruh antara variabel $\mathrm{X}$ dan variabel Y

Berdasarkan hasil uji product moment pada lampuran C4 nilai $R_{\text {hitung }}$ 0,467 dan diperoleh nilai $R_{\text {tabel }} 0,279$ sehingga didapatkan $R_{\text {hitung }} 0,467>$ $R_{\text {tabel }}$ 0,279. Berdasarkan hasil tersebut dapat disimpulkan bahwa $H_{a}$ diterima yang berarti bahwa terdapat hubungan antara parenting school terhadap hasil belajar PPKn siswa. Nilai koefisien korelasi sebesar 0,467 kemudian dikonsultasikan dengan tabel 4.6 berikut.

Tabel 4.6 Kualifikasi Korelasi

\begin{tabular}{|c|c|}
\hline Interval Koefisien & Tingkat Hubungan \\
\hline $0,00-0,199$ & Sangat rendah \\
$0,20-0,399$ & Rendah \\
$0,40-0,599$ & Sedang \\
$0,60-0,799$ & Kuat \\
$0,80-1,000$ & Sangat Kuat \\
\hline
\end{tabular}

Berdasarkan hasil koefisien korelasi sebesar 0,467 yang dikonsultasikan dengan tabel 4.6 maka dapat disimpulkan bahwa hubungan antara variabel parenting school dengan variabel hasil belajar PPKn siswa kelas V SD No. 25 Panaikang kecamatan Bissappu Kabupaten Bantaeng berada pada tingkat hubungan sedang.

\section{b. Uji Parsial (uji t)}

Adapun variabelnya adalah sebagai berikut:

$\mathrm{X}$ : kontribusi parenting school

$\mathrm{Y}$ : hasil belajar PPKn siswa kelas V SD No. 25 Panaikang Kecamatan Bissappu KabupatenBantaeng.

Hipotesis:

$H_{a}=$ ada pengaruh antara variabel $\mathrm{X}$ dan variabel Y

$H_{0}=$ tidak ada pengaruh antara variabel $\mathrm{X}$ dan variabel Y

Berdasarkan hasil uji parsial pada lampiran C4 Nilai $t_{\text {hitung }} 3,658791$ dan diperoleh nilai $t_{\text {tabel }} 2,01063$ sehingga didapatkan $\quad t_{\text {hitung }} 3,658791>t_{\text {tabel }}$ 2,01063. Berdasarkan hasil tersebut dapat disimpulkan bahwa $H_{a}$ diterima yang berarti bahwa terdapat kontribusi parenting schoolterhadap hasil belajar PPKn siswa.

\section{c. Garis Regresi}

Berdasarkan hasil perhitungan pada lampiran C4 diperoleh nilai $Y=52,5988+$ 0,640 . Berdasarkan persamaan garis regresi tersebut dapat diartikan bahwa jika kualitas nilai $X$ bertambah 1 , maka nilai rata-rata juga akan bertambah.

\section{d. Koefisien Determinasi}

Berdasarkan hasil perhitungan korelasi product moment diperoleh nilai $\mathrm{r}=$ 0,467 . Sehingga nilai koefisien determinasi atau Rsquare $=r^{2} \times 100 \%=21,8 \%$. Nilai koefisien determinasi tersebut berarti bahwa variabel parenting school memberikan kontribusi sebesar 21,8\% terhadap hasil belajar PPKn siswa kelas V SD Negeri No. 25 Panaikang Kecamatan Bissappu Kabupaten Bantaeng, sementara 78,2\% lainnya dipengaruhi oleh faktor lain.

B. Pembahasan

1. Kontribusi Parenting School

Terhadap Hasil Belajar PPKn Peserta Didik Kelas V SDN No.25 Panaikang Kecamatan Bissappu Kabupaten Bantaeng.

Hasil uji korelasi product momentpada penelitian ini yaitu $R_{h i t u n g}$ 0,467 dandiperoleh nilai $\quad R_{\text {tabel }}$ 
terhadap hasil belajar PPKn siswa.

$$
\text { Hasilujiparsial (uji }
$$

disimpulkan bahwa $H_{a}$ diterima yang

berartibahwa terdapat kontribusi

parenting schoolterhadap hasil belajar PPKn siswa.

Berdasarkan kedua hasil uji hipotesis tersebut, maka dapat dibuktikan bahwa terdapat kontribusi yang diberikan oleh parenting school terhadap hasil belajar PPKn Peserta Didik Kelas V SD Negeri No. 25 Panaikang Kecamatan Bissappu Kabupaten Bantaeng. Penelitian ini berhasil membuktikanhipotesis bahwa ada konstribusi antara Parenting School terhdap hasil belajar peserta didik kelas V SDN No. 25 Panaikang Kecamatan Bissappu Kabupaten Bantaeng.

Hasil penelitian ini sesuai dengan hasil penelitian yang dilakukan oleh Islami (2016:97) yang mendapatkan hasil bahwa terdapat hubungan yang positif antara partisipasi orang tua dengan hasil belajar siswa kelas V SDN Gugus Arief Rahman Hakim Kecamatan Kendal Kabupaten Kendal. Hal ini dapat dibuktikan dengan nilai koefisien korelasi 98 sebesar $0,559>$ dari $\mathrm{r}$ tabel 0,121 dan harga signifikansinya $0,000<$ 0,05 sehingga partisipasi orang tua berpengaruh sebanyak $56 \%$ terhadap hasil belajar IPS pada siswa kelas V SDN Gugus Arif Rahman Hakim Kecamatan Kendal Kabupaten Kendal.

Hasil penelitian ini dan penelitian olehIslami juga sesuai dengan hasil penelitian yang dilakukan oleh Rahman (2014:129) yang menyatakan bahwa kemitraan yang baik antara orang tua dengan pihak sekolah akan membawa dampak terhadap luaran kompetensikognitif, afektif, dan psikomotorik siswa yang merupakan hasil dari pelaksanaan program sekolah yang efektif. Pendapat tersebut diperkuat oleh Minke, KM, \& Anderson, KJ (2005) yang mengatakan bahwa keterlibatan orang tua dalam pendidikan yang dalam hal ini dimaksud parenting school dalam beberapa penelitian telah terbukti membawa dampak yang positif terhadap prestasi siswa, kompetensi guru, nilai siswa, nilai tes standar, dan perilaku siswa.
Pendidikan adalah proses yang akan

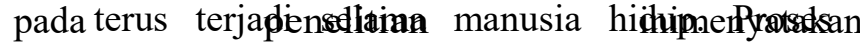
pendidikan mencakup proses belajar yangakan berdampak pada perilaku dan pengetahuan seseorang. Pengetahuan dan pengalaman yang banyak berbanding lurus dengan pengalaman belajar seseorang. Oleh karena itu partisipasi orang tua dalammendukung pembelajaran anak sangat dibutuhkan demi hasil pembelajaran yang optimal. Sehingga tingkat partisipasi orangtua akan membawa pengaruh positif pada hasil belajar yang diperoleh seorang anak (Dwiningrum, 2011:68).

\section{Proses Konstribusi Parenting School terhadap Hasil Belajar Peserta Didik Kelas V SDN No. 25 Panaikang Kecamatan Bissappu Kabupaten Bantaeng}

Hasil penelitian ini menyimpulkan bahwa tingkat parenting school orang tua peseta didik kelas V SD Negeri No. 25 Panaikang kecamatan Bissappu kabupaten Bantaeng masuk dalam kategori sedang. Sementara itu, nilai hasil belajar PPKn peseta didik kelas V SD Negeri No. 25 Panaikang kecamatan Bissappu kabupaten Bantaengmasuk dalam kategori baik sekali. Berdasarkan hasil perhitungan koefisien korelasi diperoleh nilai 0,467 yang masuk dalam kategori hubungan sedang. Selain itu, berdasarkan perhitungan garis regresi didapatkan hasil $\mathrm{Y}=52,5988+$ 0,640 yang dapat diartikan bahwa terdapat pengaruh yang positif karena nilai konstanta a adalah + 0,640. Hasil tersebut juga dapat diartikan bila nilai parenting school bertambah 1 poin maka akan menambah nilai hasil belajar siswa sebanyak 0,640 . Hasil penelitian ini juga sesuai dengan penelitian yang pernah dilakukan oleh Yusniyah (2008) tentang konstribusi Parenting School dengan hasil belajar Peserta didik, bahwa hasil penelitian diperoleh Parenting School secara umum yang diterapkan oleh orang tua dapat dikatakan cukup demokratis dan prestasi belajar Peserta didik rata-rata berada pada taraf cukup, serta hasil penelitian diperoleh korelasi yang positif dan signifikan antara Parenting School orang tua dengan prestasi belajar Peserta didik. Hal ini menunjukkan bahwa tinggi rendahnya prestasi belajar peserta didik sangat bergantung pada parenting school yang diterapkan oleh orang tua di rumah. Hasil penelitian ini memperkuat penelitian yang pernah dilakukan sebelumnya 
oleh Yusniyah (2008) bahwa penerapan parenting school dinyakini dan terbukti dapat meningkatkan prestasi belajar peserta didik, karena dengan penerapan parenting school akan membantu peserta didik tumbuh dengan baik, sehingga dapat memacu prestasi belajarnya.

Penelitian ini membuktikan bahwa anak yang dididik dengan Parenting School akan memiliki dampak positif untuk perkembangan dan kepribadian anak, sehingga akan memacu anak untuk lebih berprestasi, seperti yang dikemukakan oleh Septiari (2012:171) bahwa Parenting School yang ditandai dengan pengakuan orang tua terhadap kemampuan anak dan anak diberi kesempatan untuk tidak selalu bergantung pada orang tua akan membuat anak lebih mandiri, percaya diri, mempunyai kontrol diri, mempunyai minat terhadap hal-hal baru, patuh dan berorientasi pada hasil belajar peserta didik. Berbeda dengan anak yang tidak dididik dengan Parenting School, sehingga anak akan cenderung agresif, tidak patuh, kurang mampu mengontrol diri dan kurang memikirkan masa depannya.

Hal ini senada dengan pendapat Beumrind yang dikutip Papalia (2009:410) bahwa anak yang dididik dengan Parenting School akan cenderung mengandalkan diri, dapat mengotrol diri, lebih asertif, mengeksplorasi dan merasa aman. Sedangkan anak yang di didik dengan Parenting School akan cenderung belum matang, tidak memiliki kontrol diri dan tidak terlalu suka bereksplorasi.

Hasil penelitian ini sesuai salah satu faktor yang mempengaruhi hasil belajar menurut Purwanto (2007:104), yaitu faktor eksternal lingkungan keluarga. Dimana dukungan dari keluarga merupakan suatu pemacu semangat berprestasi seseorang. Suasana dan keadaan keluarga yang bermacam-macam mau tidak mau turut menentukan bagaimana dan sampai dimana belajar dialami dan dicapai oleh anak.

\section{SIMPULAN DAN SARAN}

Berdasarkan hasil analisis dan pembahasan tentang "Konstribusi parenting school terhadap hasil hasil belajar peserta didik SDN No. 25 Panaikang Kecamatan Bissappu Kabupaten Bantaeng", maka dapat ditarik kesimpulan sebagai berikut. 1)
Terdapat kontribusi yang diberikan oleh parenting school terhadap hasil belajar PPKn Peserta Didik Kelas V SD Negeri No. 25 Panaikang Kecamatan Bissappu Kabupaten Bantaeng. Hal tersebut berdasarkan nilai uji korelasi product moment pada penelitian ini yaitu $R_{\text {hitung }} 0,467$ yang lebih besar dari nilai $R_{\text {tabel }} 0,279$. 2) Proses kontribusi parenting school terhadap hasil belajar PPKn Peserta Didik Kelas V SD Negeri No. 25 Panaikang Kecamatan Bissappu Kabupaten Bantaeng masuk dalam kategori sedang. Berdasarkan hasil perhitungan koefisien korelasi diperoleh nilai 0,467 yang masuk dalam kategori hubungan sedang. Selain itu, nilai koefisien determinasi diperoleh $21,8 \%$ yang berarti bahwa parenting school berkontribusi rendah terhadap hasil belajar siswa.

Berdasarkan hasil penelitian dan kesimpulan yang telah diuraikan di atas maka dapat diberikan beberapa saran sebagai berikut. Diharapkan orang tua menerapkan Parenting School dalam mendidik anak, karena Parenting School dinyakini dan terbukti dapat meningkatkan hasil belajar Peserta didik. Penerapan Parenting School akan membantu Peserta didik tumbuh dengan baik, sehingga dapat memacu hasil belajarnya. Peserta didik dapat bersikap terbuka dengan orang tua terhadap masalah yang dihadapi dan bersikap positif serta selektif terhadap sikap orang tua. Apabila orang tua memiliki sikap yang mengarah pada Parenting School, maka jangan segan untuk selalu mengajak berkomunikasi agar hubungan menjadi lebihbaik. Bagi peneliti selanjutnya, disarankan agar menggunakan metode lain dalam meneliti Parenting School misalnya melalui wawancara mendalam terhadap peserta didik dan orang tuanya meskipun hanya sebagian saja, sehingga informasi yang diperoleh dapat bervariasi dan lebih kuat dari pada menggunakan sistem angket.

\section{DAFTAR PUSTAKA}

\author{
Depdiknas. 2010. Peraturan Menteri \\ Pendidikan Nasional Tentang Standar \\ Pendidikan Anak Usia Dini. Jakarta: \\ Direktorat PAUD, Dirjen Pendidikan \\ Nonformal dan Informal.
}


Djamarah.S.B.dkk. 2006. Strategi belajar mengajar. Jakarta: PT. Rineka Cipta.

Dwiningrum, Siti Irene Astuti. 2011.

Desentralisasi dan partisipasi

masyarakat dalam

pendidikan.Yogyakarta:

Pustaka Pelajar.

Minke, K. M., \& Anderson, K. J. 2005.

Family-school collaboration and

positive behavior support. Journal of

Positive Behavior Interventions, 7(3), 181.

Papalia, Diane. 2009. Human

development. Jakarta:

SalembaHumanika.

Purwanto. 2007. Psikologi pendidikan remaja. Yogyakarta: Pustaka Pelajar.

Rahman, Bujang. 2014. Kemitraan Orang Tua Dengan Sekolah Dan

Pengaruhnya Terhadap Hasil Belajar Siswa. Jurnal Pendidikan Progresif. Vol 4 No. 2

Septiari, Beti Bea (2012) Infeksi

Nosokomial. Jakarta: Nuha Medica.

Yusniyah. 2008. Hubungan Pola Asuh Orang Tua dengan Prestasi Belajar Siswa. Jurnal vol. 7 No. 2 JuliDesember Pendidikan Dasar Unnes. Semarang. 